\title{
The Policy of Bener Meriah Regency Government Model Initiation in Evaluating the Use of Village Development Funds
}

\author{
Salawati ${ }^{1}$, Praptining Sukowati ${ }^{2}$, Sri Hartini Djatmikowati ${ }^{2}$ \\ ${ }^{1}$ Master Student in University of Merdeka Malang, Indonesia \\ ${ }^{2}$ Lecturer in University of Merdeka Malang, Indonesia \\ Email: Laylinuriani95@gmail.com
}

\begin{abstract}
:
Initiation is the policy of the Bener Meriah Regency Government to evaluate the use of funds in development at the village level so that the use of funds is more targeted. Considering the existence of the village as a government organization has certain authority to manage and regulate the residents in this matter, the village is at the forefront in achieving development success, it is necessary to have an evaluation to lead to improvement. The initiation policy in evaluating as a model or new breakthrough by the District Government of Bener Meriah how to give appreciation in the form of additional funding for villages that can manage the budget on time, on quality and on target. To implement the policy model, a legal umbrella has been prepared in the form of a Perbub. The research objective is to describe and analyze the initiation policy model of the Bener Meriah Regency Government in evaluating the use of village development funds and To find out and analyze the initiation policy model strategy carried out by the Bener Meriah Regency Government in evaluating the use of village development funds. The method is a procedure carried out to find out something using systematic steps, so in this study the researcher used a descriptive qualitative method to describe the initiation policy model in evaluating the use of village development funds. Determination of informants was carried out by purposive sampling, while data collection techniques through observation and interview. The results showed that the policy model of the initiation of the Bener Meriah Regency Government in evaluating the use of village development funds as a new breakthrough was born because it was based on the improper use of funds amidst the abundance of the budget given by the government. The initiation policy model strategy undertaken by the Bener Meriah Regency Government in evaluating the use of village development funds through musrembang which then enters the implementation stage through the link between the results of the development planning and implementation becomes an evaluation of the use of funds.

Keywords:

policy model; government initiation; evaluation of fund usage
\end{abstract}

\section{Introduction}

Development at the village level is an integral part of national development, because the village is the basis of overall national development, based on the principle of development that was born from the wishes of the community, carried out by the community and also fully in the interests of the community. One of the initiatives from the central government is to achieve accelerated development through effective public financing, in order to support infrastructure development evenly in all districts/cities.

In connection with the initiative of Bener Meriah Regency Government to evaluate the use of village development funds aims to improve the performance of village apparatus and to accelerate development through the budget provided by the government through 
comprehensive community involvement. Considering the amount of funds obtained by the village as direct assistance allocated to the Village Government is used to improve community service facilities, institutions and village infrastructure that are needed and prioritized by the community, the utilization and administration of its management carried out and accounted for by the Village Head.

Community groups that still maintain the local culture in the practice of pregnancy care The initiative of Bener Meriah Regency Government to evaluate the use of funds in the implementation of village-based development is very necessary for community involvement or participation. Participation can move the community in development activities as a real substance of the willingness of the local community to access the potential of existing resources in their environment. So that the potential of very abundant resources can be used as added value for improving people's welfare. The existence of the village as a government organization has certain authority to manage and regulate citizens in this case, the village is at the forefront in achieving development success, it is necessary to have an evaluation towards improvement.

Bener Meriah Regency Government has initiated the birth of a village development evaluation policy model by giving appreciation in the form of providing additional funds to villages that can manage the budget on time, on quality and on target. To implement the policy model, it is necessary to have the participation of the community and needs to be supported by various parties as well as the need to increase the Human Resources (HR) of the village apparatus in managing village funds. Likewise with the use of the budget which has so far been largely used for infrastructure development, while in the economic sector the budget allocation is very little. Whereas on the other hand one of the objectives of evaluating the use of funds in village development for the economic development of the community.

\section{Review of Literature}

\subsection{Evaluation Theory}

Basically, evaluation is a way to evaluate an activity or policy related to an existing program. Evaluation is very much needed and becomes one of the levels in the process of public policy making. Evaluations in public policy serve as analytical tools and procedures intended to do two main things. The first thing, evaluation research, as an analytical tool involves a policy program to get all information related to work assessment, process and results. Second, evaluation as a phase of the more general policy cycle refers to reporting the information back to the policy making process.

One evaluation method conducted by Bener Meriah Government is an evaluation of program efficiency. Program efficiency evaluation is an evaluation that focuses on efficiency with a tendency to improve the mechanism / process of a program in achieving development goals. At the program level, several things that need to be evaluated include comparing between targets and achievements, both in terms of indicators and budgeting. In addition, it should be noted also about administrative and technical obstacles in implementing the specified program. In this case, it is seen the percentage of total program costs realized per target achievement against the estimated total program costs per estimated target achievement. This means it is much related to time. Percentage of total program costs realized per time realization of the estimated total program costs per estimated time (fixed target). 
In implementing the program efficiency evaluation several steps must be carried out as follows: (1) Determination of the targets to be achieved by the program, (2) Determination of program target indicators, (3) Costs required to achieve program targets (4) Realization of program implementation, (5) Determination of stakeholders who benefit from the program, (6) Preparation of the program evaluation format, and (7) Determination of analysis methods. Evaluation of development programs, both medium and annual, is carried out every year, after the end of the fiscal year and before the preparation of further program plans.

Evaluation as an initiation of the effectiveness of program design is an evaluation carried out in an effort to improve the performance of development programs. The focus of program design evaluation is emphasized on the targets to be achieved by the program and the beneficiary stakeholders of the program. By using the PART (The Program Rating Tool) approach which is a diagnostic tool used to find out the overall effectiveness of the program in order to: (i) assess program performance, and (ii) lead towards improving program performance. The program evaluation carried out using PART is comprehensive, starting from how well the program was designed, how well the program was carried out, to what the results were achieved.

Villages have the autonomy to make various separate policies in the administration of their Governments. But the autonomy that is owned is autonomy based on origins and customs. This means that the autonomy is not a result of laws and regulations, but rather comes from the origins and customs of the village developed, maintained, and used by the village community from the past until now. However, the use of village funds is often not on target so the district government needs to make policies related to the evaluation of the use of the budget that has been carried out by the village.

\subsection{Theory of Public Policy Implementation}

To improve the quality and quantity of the program, the government of Bener Meriah Regency puts forward various policies in implementing various programs. Implementation means an activity that is related to the completion of a job by the use of facilities (tools) to obtain results. According to Sadhana (2011: 172) Public policy implementation can be interpreted as "The activity of the completion or implementation of a public policy that has been determined by the use of means (tools) to achieve policy objectives".

In this case public policy relates to whatever is decided by the government to do or not do something. This can be in the form of regulations, including translation into various operational guidelines, program plans and activities, actors / actors and their target groups. In other words, a policy or program must be implemented so that it has the desired impact or goals.

According Sukowati (2011: 12) "Policy in the context of government and community relations is commonly referred to as public policy". This is increasingly clear with the concept of policy from Freidrich in Islamy (2011: 3) which defines policy, namely "as a series of actions proposed by a person, group or government in a particular environment by pointing out the obstacles and opportunities for implementing the proposed policy to achieving goals".

In his role for problem solving, Dunn in Tanto (2012: 30) argues that important stages in solving public problems through policy are:

a. Setting the policy agenda (agenda setting)

b. Policy formulation (policy formulation) 
c. Policy adoption (policy adoption)

d. Policy Implementation

e. Policy Assessment

\subsection{Development Theory}

Development at the village level in the district of Bener Meriah with a pattern of approach that involves the participation of the community in general not only as an object but also as a subject of development, so that the nuances developed in development are really from the bottom (buttom-up approach). In the pattern of participatory development approaches that are being developed by the government in the management of village budgets, there is a marked involvement of villagers in carrying out development, planning, implementation, and supervision of development programs that are in that scope.

Development in general can be interpreted as a process of continuous change to achieve a better situation based on certain norms. Korten (2006: 65) said that "Development which is oriented to human development, in its implementation requires a direct involvement in the community receiving the development program, because only with the participation of the community receiving the program, the results of this development will be in accordance with the aspirations and needs of the community itself".

Soetomo (2012) development is "Giving authority to the community to manage their own development processes. The intended authority encompasses the entire process from the identification of problems and needs, planning, implementation and evaluation. Whereas Todaro (2000) stated "development is a multidimential process that includes changes in social structure, community attitudes, national institutions, as well as increasing economic growth, reducing inequality and eradicating poverty".

\section{Research Method}

Method is a procedure carried out to find out something using systematic steps, then in this study the researchers used a descriptive qualitative method to describe the policy model of the initiation of the district government that is really lively in evaluating the use of village development funds. In line with this intention, Moleong (2014: 6) argues that "qualitative research is based on efforts to build the views of those who are studied in detail, formed with words, holistic and complicated images".

Sugiyono (2010: 8) defines qualitative research methods as "naturalistic research methods because his research is carried out in natural conditions (natural setting). In this study, informants were determined by purposive sampling with data collection techniques that researchers do through observation and interviews. Whereas the data analysis was carried out since before entering the field, during the field, and after completion in the field, which began by examining all available data from various sources, namely from interviews and observations that had been written in the field notes. The validity of the data is done by observing perseverance, data triangulation and discussion with colleagues.

\section{Result and Discussion}

The results showed that the policy model of the initiation of Bener Meriah Regency Government in evaluating the use of village development funds as a new breakthrough was born because it was based on the use of improper quality of funds amidst the abundance of 
budget provided by the government, then the use of the budget prioritized infrastructure development so that it had not can improve the community's economy. Therefore, Bener Meriah Regency Government has initiated a number of policies and one of these policies is the Regional regulation in evaluating the use of village development funds from budget and program planning, program implementation to the level of report preparation. Based on the policy, Bener Meriah Regency Government wants to give birth to a new model by giving special appreciation to villages that can deliver development beyond the budget target.

In connection with the strategy model of the initiation policy conducted by Bener Meriah Regency Government in evaluating the use of village development funds carried out since the village development program which then enters the implementation stage through the link between the development results and implementation becomes an evaluation of the use of funds. In this case the strategy was born in evaluating the program, evaluating the village income budget as well as evaluating the process and results of village development. Program evaluation is related to the type of development program that has been carried out prioritizing infrastructure and ignoring economic programs that can lead the community towards prosperity. In this case the government's strategy to produce various programs that are diverse but in the context of creativity in the field of development leads to an increase in village income. Then related to the budgetary income of the village from the results of research that the budget of the village known as the APK (incoming) from various original sources of the village must be allocated for development towards development in the field of increasing family income.

\section{Conclusion}

The conclusion of the research shows that the model of the initiation policy of Bener Meriah Regency Government that began with the issuance of Regional regulation \evaluating the use of village development funds had a positive and participative type of development and no longer justified all funds were prioritized in physical development alone, also a balance with productive development. This can be seen from the planning and implementation as well as in making reports of budgetary accountability or funding for settlement development reflected in various creative programs from the community. With this policy, it turns out that it can give birth to a new model in the development of village development, as well as a motivation for the community due to additional stimulant funds provided by the Regent in the village that can manage development finance properly based on the Regional regulation.

While the initiation policy strategy undertaken by Bener Meriah Government in evaluating the use of village development funds was carried out during village meetings to give birth to a development program. Strategies in evaluating programs, evaluating village income budgets as well as evaluating the process and results of village development are marked by the priority scale in programs that touch the lives of many people, especially programs that are related to increasing family income. The strategy turned out to have a greater positive impact when compared to previous village financial management. 


\section{References}

Islamy, M. Irfan. (2011). Prinsip-Prinsip Perumusan Kebijakan Negara. Jakarta: Bumi Aksara. Korten, David. C. (2006). Pembangunan Yang Memihak Rakyat. Kupasan tentang teori dan metode pembangunan. Jakarta: Lembagan Studi Pembangunan.

Moleong, Lexy. J. (2014). Metode Penelitian Kualitatif. Bandung: Remaja Rosdakarya.

Sadhana, Kridawati. (2011). Realitas Kebijakan Publik. Malang: Universitas Negeri Malang (UM Press).

Soetomo. (2012). Pembangunan Masyarakat. Merangkai Sebuah Kerangka. Yogyakarta: Pustaka Pelajar.

Sugiyono. (2010). Metode Penelitian Kuantitatif Kualitatif dan R \& D. Cetakan ketujuh. Bandung: Alfabeta.

Sukowati, Praptining. (2011). Perubahan Sosial \& Kebijakan Pembangunan Berwawasan Lingkungan. Malang: Bayumedia Publishing.

Tanto, Wasistiono. (2012). Pembangunan berparadikma Ganda dari top dawn sampai buton up. Jakarta: Raja Grafindo Persada.

Todaro, P.M, Smith S.C. (2000). Pembangunan Ekonomi di Dunia Ketiga Jakarta: Erlangga. 